\title{
Quality of life in caregivers of pediatric patients with cerebral palsy and gastrostomy tube feeding
}

\author{
Aldvan Alves FIGUEIREDO, Elizete Aparecida LOMAZI, Maria Augusta MONTENEGRO and \\ Maria Angela BELLOMO-BRANDÃO
}

Received: 13 June 2019 Accepted: 13 December 2019

\begin{abstract}
Background - Cerebral palsy is the most common cause of physical disability in childhood. Caregivers of patients presenting tetraparesis cerebral palsy (TCP) and gastrostomy tube feeding (GTF) were selected for this study because both conditions represent a great demand for their caregivers. Objective - To describe the quality of life related to the state of health of caregivers of patients with TCP who were fed by gastrostomy, to assess the results linked to the mental health of these caregivers, to compare our data with data from other studies on children with cerebral palsy without gastrostomy and to evaluate the possible interference of gastrostomy in the quality of life. Methods - A number of 30 major caregivers were interviewed and assessed. Quality of life and mental health tools applied and analyzed only for caregivers were: Medical Outcomes Study (MOS) 36-item Short Form Health Survey (SF-36), WHOQOL-BREF and Beck scales. Other information (age, gender, marital status, number of residents per household and psychological support) was evaluated. The Spearman's rank correlation coefficient was used to analyze. A $5 \%$ significance level was adopted. Results - Results obtained through questionnaires are as follows: moderate hopelessness in $20 \%$ of caregivers (the higher the number of residents per household the higher the level of caregiver's hopelessness); moderate and severe anxiety in 33.33\% of the sample studied; moderate and severe depression identified in $46.67 \%$ of interviewed caregivers; health-related quality of life of caregivers of patients with TCP were found to be below world averages; no significant figures for suicide potential were noted for the population under this study. Conclusion - The HRQOL of caregivers of TCP patients who were fed by gastrostomy is below the average of the general population. Our results are very similar to those found in other studies that evaluated caregivers of patients with cerebral palsy with different degrees of neurological impairment and no report of using GTF, suggesting that the presence of gastrostomy did not negatively interfere with the caregiver's HRQOL.
\end{abstract}

HEADINGS - Quality of life. Caregivers. Cerebral palsy. Gastrostomy.

\section{INTRODUCTION}

Cerebral palsy $(\mathrm{CP})$ is the most common cause of physical disability in childhood and occurs in 1:500 children ${ }^{(1)}$. CP includes a series of permanent movement and posture disorders ${ }^{(2)}$ which cause activity limitation attributed to non-progressive disorders that have occurred in the fetus' or developing infant's brain ${ }^{(3)}$. Its etiology is greatly diverse being neonatal anoxia the most frequent $t^{(1)}$. The degree of impairment can vary from mild symptoms to a quadriplegia condition $^{(2)}$. Patients with major impairment - Gross Motor Function Classification System (GMFSC) level $\mathrm{V}^{(3,4)}$ - require more intensive care as these individuals are totally dependent. Some of them may require the use of Gastrostomy Tube Feeding (GTF) that is usually indicated for children who have feeding difficulties, failure to thrive and dysphagia ${ }^{(5)}$. Besides notable benefits with the use of $\mathrm{GTF}^{(6)}$, both conditions require great care and can represent a challenge to the quality of life of patients and caregivers. Evaluating quality of life as a measure of the outcome of the GTF, may help to decide on the insertion of GTF, even though the improvement in nutrition may be perceived as limited gain if there is loss of quality of life.

The approach and concept for health-related quality of life (HRQOL) have shown to be very promising in the healthcare area because it focuses on the self-perception aspects concerning the wellbeing of the person involved or related to the illnesses and/or health care ${ }^{(6-8)}$. Generic quality of life tools were used to describe this self-perception ${ }^{(9)}$.

Caregivers of children and adolescents with $\mathrm{CP}$ have peculiar characteristics, not contemplated in studies that evaluate the quality of life in adults with varied indications of GTF. The aim of this study is to describe the caregivers' HRQOL during the course of their care procedures towards CP patients, to assess the mental level results for these caregivers, to compare our data with data from other studies on children with $\mathrm{CP}$ and no report of using GTF, in order to evaluate the possible interference of GTF in the quality of life.

\section{METHODS}

A qualitative and quantitative study was conducted using specific groups and individual interviews with family caregivers. All participants signed an informed consent form and approved by the Research Ethics Committee of Unicamp (no. 826.972).

Participating caregivers consisted of 30 major caregivers of Tetraparetic Cerebral Palsy (TCP) patients - GMFSC level V - who were fed by GTF and seen at Pediatric Gastroenterology department of Hospital de Clínicas of Universidade Estadual de Campinas identified through electronic medical records.

Trained researchers conducted the interviews with caregivers based on a social and informative questionnaire about the patient 
and his/her family. Researchers interviewed the participants after the routine appointments with the various professionals (pediatricians, nutritionists, neurologists) or during the hospitalization period. The interviews had an average duration of 50 minutes and followed a pre-formulated questionnaire containing the main information concerning the caregiver and the family environment. The questionnaire consisted of eight objective questions of multiple choice and easy understanding and included the following independent variables: age, gender, marital status, number of residents per household and types of support obtained. The LQ tools such as Medical Outcomes Study (MOS) 36-item Short Form Health Survey $(\mathrm{SF}-36)^{(9)}$, WHOQOL-BREF ${ }^{(10)}$ and Beck scales $^{(11)}$ were also applied.

The research analysis team consisted of two medical researchers specialized in Pediatric Gastroenterology and one psychologist researcher. The Spearman's rank correlation coefficient was used to analyze caregiver's age, number of residents per household and HRQOL evaluation tools: Medical Outcomes Study (MOS) 36-item Short Form Health Survey (SF-36),8 WHOQOL-BREF10 and Beck scales. A 5\% significance level was adopted.

\section{MOS-SF-36}

The MOS-SF-36 is a multidimensional tool comprising 36 items that evaluate two items: the physical health component (PHC) and the mental health component (MHC). The PHC presents the following dimensions: functional capacity $(\mathrm{FC})$ which includes performance of daily activities such as one's capacity of self-care, getting dressed, bathing and climbing stairs; physical aspects (PA), that is, impact on physical health resulting from the performance of daily and/or professional activities; pain (pain level and impact on the performance of daily and/or professional activities); general health state (GHS) which refers to the subjective perception of the GHS. The MHC presents the following dimensions: vitality (VT) which is the subjective perception of the health state; social aspects (SA) which reflects the physical health condition during social activities; emotional aspects (EA) reflect the emotional conditions during the performance of daily and/or professional activities; and mental health $(\mathrm{MH})$ reflects mood and well-being ${ }^{(12,13)}$.

\section{WHOQOL-BREF}

The WHOQOL-BREF(14) comprises four QOL domains: Domain I - physical domain. Domain II - psychological domain. Domain III - social relationships (personal relationships; social support; sexual activity). Domain IV - environment; opportunities for acquiring new information and skills; participation and opportunities in entertainment/leisure; physical environment (pollution/ noise/traffic/climate); transportation. In addition to these domains, the first two questions of the WHOQOL-BREF assess the global QOL and general health perception ${ }^{(7,10,14)}$.

\section{Beck scales}

The Beck scales ${ }^{(12)}$ consist of four scalar measures: Beck Depression Inventory (BDI) ${ }^{(15)}$; Beck Anxiety Inventory (BAI); Beck Hopelessness Scale (BHS); Beck Scale for Suicide Ideation (BSS ${ }^{(16)}$.

\section{RESULTS}

Thirty caregivers were included. The median age was 39 years old (23-59); all women; 21 married, eight single and one widow. TCP patients were taken care by their mothers and grandmothers. Median age of TCP patients was seven years old (4-19).

All caregivers had no home support such as home nursing, personal care services, or home medical care.

Sample characteristics and questionnaires' results are showed in TABLE 1.

TABLE 1. Characteristics of caregivers: age of tetraparetic cerebral palsy patients, age of the main caregiver(mother-grandmother), number of inhabitants per household and results according to the MOS-SF-36, WHOQOL-BREF and Beck scales of caregivers.

\begin{tabular}{|c|c|c|c|c|c|c|c|}
\hline & Variable & $\mathbf{N}$ & Mean & SD & Minimum & Median & Maximum \\
\hline \multirow{2}{*}{ 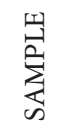 } & TCP patient's age (years) & 30 & 8.60 & 4.43 & 4.00 & 7.00 & 19.00 \\
\hline & Caregiver's age (mother-grandmother) (years) & 30 & 39.70 & 9.04 & 23.00 & 39.00 & 59.00 \\
\hline $\begin{array}{l}0 \\
n \\
1 \\
n \\
n \\
0 \\
0 \\
\Sigma\end{array}$ & $\begin{array}{l}\text { Physical Health Components } \\
\text { FC } \\
\text { PA } \\
\text { Pain } \\
\text { GHS } \\
\text { Mental Health Components } \\
\text { VT } \\
\text { AS } \\
\text { EA } \\
\text { MH }\end{array}$ & $\begin{array}{l}30 \\
30 \\
30 \\
30 \\
\\
30 \\
30 \\
30 \\
30\end{array}$ & $\begin{array}{l}71.17 \\
51.67 \\
55.1 \\
63.93 \\
48 \\
72.08 \\
53.33 \\
59.07\end{array}$ & $\begin{array}{l}26.74 \\
35.92 \\
25.98 \\
16.68 \\
\\
19.28 \\
28.56 \\
43.42 \\
20.39\end{array}$ & $\begin{array}{c}10 \\
0 \\
10 \\
25 \\
10 \\
0 \\
0 \\
16\end{array}$ & $\begin{array}{c}80 \\
50 \\
51 \\
64.5\end{array}$ & $\begin{array}{c}75 \\
100 \\
100 \\
92\end{array}$ \\
\hline 记焉 & $\begin{array}{l}\text { BDI } \\
\text { BAI } \\
\text { BHS }\end{array}$ & $\begin{array}{l}30 \\
30 \\
30\end{array}$ & $\begin{array}{c}15.67 \\
14.53 \\
5.3\end{array}$ & $\begin{array}{l}9.96 \\
8.02 \\
3.31\end{array}$ & $\begin{array}{l}0 \\
3 \\
0\end{array}$ & $\begin{array}{c}14 \\
15 \\
4\end{array}$ & $\begin{array}{l}43 \\
30 \\
13\end{array}$ \\
\hline
\end{tabular}

FC: functional capacity; PA: physical aspects; GHS: general health state; VT: vitality; SA: social aspects; EA: emotional aspects; MH: mental health; BDI: Beck Depression Inventory; BAI Beck Anxiety Inventory; BHS: Beck Hopelessness Scale. 
The MOS-SF-36 (CP and SA domains) presented an average of $71.17 \%$ and $72.08 \%$ respectively. The GHS domain presented an average of $63.93 \%$, whereas the PA, pain, EA and $\mathrm{MH}$ domains averages of $51.67 \%, 55.1 \%, 53.33 \%$, and $59.07 \%$, respectively. And the VT domain showed an average of $48 \%$.

The WHOQO-BREF presented an average of $62.26 \%$ in the physical domain; $62.64 \%$ in the psychological domain; $54.44 \%$ in the social relationship's domain; and $52.71 \%$ in the environment domain. The questions relating to general health the average was $44.17 \%$ and $46.67 \%$ for health satisfaction.

As for the of results of the BDI (Beck scales), $30 \%$ of caregivers presented mild depression, $23.33 \%$ moderate depression and $10 \%$, severe depression. The BAI showed $36.67 \%$ of caregivers with moderate anxiety, $10 \%$ with severe anxiety, $23.33 \%$ with mild anxiety, and $30 \%$ with minimum anxiety. With regard to the BHS, $53.33 \%$ of caregivers presented the minimum hopelessness level, $26.67 \%$ presented mild hopelessness and $20 \%$ claimed to experience moderate hopelessness. On the results for BSS, only three caregivers $(\mathrm{n}=3$, considered very low) presented positive response to suicide ideation and 27 caregivers' negative response.

Results found through the questionnaires used were: moderate hopelessness in $20 \%$ of caregivers (the higher the number of residents per household, the higher the caregivers' hopelessness), moderate and severe anxiety in $33.33 \%$ of the sample, moderate and severe depression in $46.67 \%$ of caregivers interviewed.

In the MOS-SF-36 for HRQOL, the dimensions FC and SA presented the best averages. Only the domain VT had a HRQOL below the general population average.

TABLE 2 shows results of correlation of Beck scales, WHOQOL-BREF and MOS-SF-36 with caregiver's age and the number of residents per household. There was no statistically significant difference regarding age. However, there was a statistically significant difference about number of residents per household in BHS $(P=0.0310)$ and $\mathrm{MH}(P=0.0024)$.

On the questionnaire answered by the TCP caregivers regarding their desire to have psychological support, $46.67 \%$ wished to have such support and 53.33\% didn't.

\section{DISCUSSION}

The HRQOL of caregivers of TCP patients, who were fed by GTF, according to our study, is below the average of the general population. Caregivers' age is not significantly correlated with their HRQOL nor with the Beck scales (BDI, BAI and BHS).

Upon observation of the BDI results, $30 \%$ of caregivers presented mild depression, $23.33 \%$, moderate depression, and $10 \%$ severe depression; while $36.67 \%$ presented moderate anxiety. We observed that the higher the number of residents per household, the higher caregiver's level of hopelessness (BHS).

According to a research by Ware ${ }^{(9)}$, the average score for FC domain of MOS-SF-36 in developed countries is between 80 and 90 whereas the average score for VT is below 60 (on a 100-point scale) in the general population. Whenever a scale score is below 50 , the caregivers' health state is below average.

The WHOQOL-BREF is considered satisfactory when the respective average is above $50 \%$. We observed that the general health and health satisfaction domains of WHOQOL-BREF are below these figures.

We found no studies on HRQOL and QOL of caregiver's TCP patients who were related to be fed by GTF. We found research
TABLE 2. Correlation of Beck scales, WHOQOL-BREF and MOS-SF-36 with caregiver's age and the number of residents per household.

\begin{tabular}{|c|c|c|}
\hline & $\begin{array}{c}\text { Main } \\
\text { caregiver's age }\end{array}$ & $\begin{array}{l}\text { Residents per } \\
\text { household }\end{array}$ \\
\hline \multicolumn{3}{|l|}{ Beck scales } \\
\hline BDI & 0.19996 & -0.19696 \\
\hline$P$ value & 0.2894 & 0.4609 \\
\hline BAI & 0.29189 & 0.19921 \\
\hline$P$ value & 0.1176 & 0.2913 \\
\hline BHS & 0.05721 & 0.39447 \\
\hline$P$ value & 0.7640 & 0.0310 \\
\hline \multicolumn{3}{|l|}{ WHOQOL-BREF } \\
\hline Physical health domain & -0.05046 & -0.18778 \\
\hline$P$ value & 0.7912 & 0.3204 \\
\hline Psychological domain & 0.06506 & -0.10057 \\
\hline$P$ value & 0.7327 & 0.5970 \\
\hline Social relationships domain & 0.09053 & -0.15971 \\
\hline$P$ value & 0.6342 & 0.3992 \\
\hline Environment domain & 0.03412 & -0.19696 \\
\hline$P$ value & 0.8580 & 0.2968 \\
\hline General health domain & 0.06285 & 0.05630 \\
\hline$P$ value & 0.7414 & 0.7676 \\
\hline Satisfaction with health domain & 0.18524 & 0.15515 \\
\hline$P$ value & 0.3271 & 0.4130 \\
\hline \multicolumn{3}{|l|}{ MOS-SF-36 } \\
\hline FC & -0.35778 & -0.12002 \\
\hline$P$ value & 0.0522 & 0.5276 \\
\hline PA & -0.23839 & 0.27611 \\
\hline$P$ value & 0.2046 & 0.1397 \\
\hline Pain & -0.34799 & -0.04775 \\
\hline$P$ value & 0.0595 & 0.8022 \\
\hline GHS & 0.35526 & -0.19505 \\
\hline$P$ value & 0.0540 & 0.3017 \\
\hline VT & 0.03471 & -0.11855 \\
\hline$P$ value & 0.8555 & 0.5327 \\
\hline AS & 0.12700 & -0.04312 \\
\hline$P$ value & 0.5036 & 0.8210 \\
\hline EA & -0.15142 & -0.00829 \\
\hline$P$ value & 0.4244 & 0.9653 \\
\hline $\mathrm{MH}$ & -0.20341 & -0.53377 \\
\hline$P$ value & 0.2810 & 0.0024 \\
\hline
\end{tabular}

BDI: Beck Depression Inventory; BAI: Beck Anxiety Inventory; BHS: Beck Hopelessness Scale. FC: functional capacity; PA: physical aspects; GHS: general health state; VT: vitality; SA: social aspects; EA: emotional aspects; $\mathrm{MH}$ : mental health; statistical analyses: Spearman coefficient.

with heterogeneous Gross Motor Function Classification System (GMFSC). When looking at these studies ${ }^{(17-21)}$, we identified figures very similar to those found in the present study. In social relationships and Environment domains of the WHOQOL-BREF, the averages detected are similar because they tend to present lower numbers. In general health and health satisfaction domains of the WHOQOL-BREF no references of such figures were found.

The MOS-SF-36 was translated, validated and culturally adapted to Brazil in 1997 by Ciconelli(13) who used women patients 
with rheumatoid arthritis. In our study, caregivers (median age 39 years old) presented HRQOL below the average found in women who were diagnosed with rheumatoid arthritis, whose age was between 42 and 49 years old ${ }^{(13)}$.

The VT domain of MOS-SF-36 presented below the average in our study and in others as well ${ }^{(22,23,24)}$. According to Ünalan et al. ${ }^{(24)}$, the results below the average of the general population are: PA, VT, SA, EA, MH. We noted that the average for the pain domain of MOS-SF-36 in our research was similar.

Studies that used the MOS-SF-36 include CP with varying degrees of impairments and no report of using $\mathrm{GTF}^{(25-29)}$. It is possible that some patients used GFT in these studies, but compared to our sample, which all patients were using GTF, we observed very similar results, suggesting that the presence of the GTF didn't interfere with caregivers' HRQOL.

Edwards \& Leafman ${ }^{(30)}$ studied perceptions of caregivers of children with special health care needs of Gastrostomy Buttons, suggesting general satisfaction. Placement of gastrostomy button had several effects for children with developmental disabilities and their families. So, the caregivers should be well informed about this procedure.

A study in adults, the HRQL for patients and caregivers was evaluated before and after the GTF and the results were comparable to those of the control patients, suggesting that GTF preserves but does not improve quality of life of patients and caregivers ${ }^{(31)}$.

According to research conducted by Brehaut ${ }^{(32)}$, caregivers of CP children (multiple levels of GMFCS) presented a higher predisposition to decreased physical well-being, followed by the onset of back pain, migraine, intestinal or stomach ulcer, asthma or arthritis/rheumatism, as well as an increased number of chronic physical diseases.

The MH domain of the MOS-SF-36 is correlated with the number of residents in the same household. The greater the number of residents per household, the worse were the mental health.
According to their responses regarding the need of having or not psychological support, the majority expressed no desire to be provided with psychological support. In the research conducted by Eyigor ${ }^{(22)}$ with caregivers of children who had cancer, among the mothers 58\% expressed their desire in sharing their experiences with another person and 46\% expressed the need for psychological support. We noted that caregivers of chronic patients have a greater need of being heard and embraced. However, caregivers of TCP patients claim that it will not solve the situation, so they formed isolated groups of caregivers in the same situation.

The main limitation of our study is that we were not able to perform a cross-reference of qualitative data with the life history of each caregiver. This may be addressed in another study.

\section{CONCLUSION}

Our study on the mental health and HRQOL of caregivers of TCP patients who were fed by GTF is the most comprehensive to date. Our results are very similar to those found in other studies evaluating caregivers of patients with $\mathrm{CP}$ with different degrees of neurological impairment and no report of using GTF, suggesting that the presence of gastrostomy had no negative effect on HRQOL of caregivers.

\section{Authors' contribution}

Figueiredo AA: lead researcher and article author. Lomazi EA: contribution with correction. Montenegro MA: help in obtaining data. Bellomo-Brandão MA: project supervisor and article author.

\section{Orcid}

Aldvan Alves Figueiredo: 0000-0002-8242-0433.

Elizete Aparecida Lomazi: 0000-0001-5504-4746.

Maria Augusta Montenegro: 0000-0002-3609-2774.

Maria Angela Bellomo Brandão: 0000-0002-1145-2606.

Figueiredo AA, Lomazi EA, Montenegro MA, Bellomo-Brandão MA. Qualidade de vida em cuidadores de pacientes pediátricos com paralisia cerebral alimentados por gastrostomia. Arq Gastroenterol. 2020;57(1):3-7.

RESUMO - Contexto - A paralisia cerebral é a causa mais comum de incapacidade física na infância. Cuidadores principais de pacientes que apresentam paralisia cerebral tetraparética (PCT) em alimentação por tubo de gastrostomia foram selecionados para este estudo porque ambas as condições representam uma grande demanda para seus cuidadores. Objetivo - Descrever a qualidade de vida relacionada à saúde (QVRS) de cuidadores de pacientes com PCT alimentados por gastrostomia e avaliar os resultados relacionados a sua saúde mental, comparar nossos dados com dados de outros estudos em cuidadores de crianças com paralisia cerebral sem gastrostomia e avaliar a possível interferência da gastrostomia na qualidade de vida dessa população. Métodos - Trinta cuidadores foram entrevistados e avaliados. Os instrumentos de qualidade de vida e saúde mental foram aplicados e analisados apenas para os cuidadores foram: Medical Outcomes Study 36-item Short Form Health Survey, WHOQOL-BREF e escalas Beck. Outras informações (sexo, idade, estado civil, número de habitantes na mesma casa e suporte psicológico) foram avaliadas. O coeficiente de correlação de Spearman foi utilizado na análise estatística. Foi adotado um nível de significância de 5\%. Resultados - Os resultados obtidos por meio de questionários são os seguintes: desesperança moderada identificada em $20 \%$ dos cuidadores (quanto maior o número de moradores por domicílio, maior o nível de desesperança do cuidador); 33,33\% demonstraram ansiedade moderada e grave; 46,67\% depressão moderada e grave; a qualidade de vida relacionada à saúde de cuidadores de pacientes com PCT mostrou-se abaixo da média mundial; não foram observados números significativos de potencial suicida. Conclusão - A QVRS dos cuidadores de pacientes com PCT alimentados por gastrostomia está abaixo da média da população geral. Nossos resultados são muito semelhantes aos encontrados em outros estudos que avaliaram cuidadores de pacientes com paralisia cerebral com diferentes graus de comprometimento neurológico e sem relato de alimentação por gastrostomia, sugerindo que a presença da gastrostomia não interferiu negativamente na QVRS dos cuidadores.

DESCRITORES - Qualidade de vida. Cuidadores. Paralisia cerebral. Gastrostomia. 


\section{REFERENCES}

1. Stanley FJ, Blair E, Alberman E. Cerebral palsies: epidemiology and causal pathways. Cambridge University Press, 2000.

2. Palisano R, Rosenbaum P, Walter S, Russell D, Wood E, Galuppi B. Development and reliability of a system to classify gross motor function in children with cerebral palsy. Dev Med Child Neurol. 1997;39:214-23.

3. Rosenbaum P, Paneth N, Leviton A, Goldstein M, Bax M, Damiano D, et al. A report: the definition and classification of cerebral palsy April 2006. Dev Med Child Neurol Suppl. 2007;109:8-14.

4. Wood E, Rosenbaum P. The gross motor function classification system for cerebral palsy: a study of reliability and stability over time. Dev Med Child Neurol. 2000;42:292-6.

5. Caselli TB, Lomazi EA, Montenegro MAS, Bellomo-Brandão MA. Comparative study on gastrostomy and orally nutrition of children and adolescents with tetraparesis cerebral palsy. Arq Gastroenterol. 2017;54:292-6.

6. Guyatt GH, Feeny David H, Patrick DL. Measuring health-related quality of life. Ann Intern Med. 1993;118:622-9.

7. The WHOQOL Group. The World Health Organization Quality of Life Assessment (WHOQOL): development and general psychometric properties. Soc Sci Med. 1998;46:1569-85.

8. Felce D, Perry J. Quality of life: Its definition and measurement. Res Dev Disabil. 1995; 16:51-74.

9. Ware JE, Snow KK, Kosinski M, Gandek B. SF-36 Health Survey Manual and Interpretation Guide. Boston. Massachusetts: New England Medical Center. The Health Institute; 1993.

10. The WHOQOL Group. World Health O. WHOQOL-bref: Introduction, administration, scoring and generic version of the assessment: field trial version, December 1996, Geneva.

11. Cunha JA. Manual da versão em português das Escalas Beck. São Paulo: Casa do Psicólogo. 2001:11-3.

12. Ware JE, Jr. SF-36 health survey update. Spine (Phila Pa 1976). 2000;25:3130-9.

13. Ciconelli RM, Ferraz MB, Santos W, Mein Ao I, Quaresma MR. Brazilian-Portuguese version of the SF-36. A reliable and valid quality of life outcome measure. Rev Bras Reumatol. 1999;39:143-50.

14. The WHOQOL Group. Development of the World Health Organization WHOQOL-BREF quality of life assessment. The WHOQOL Group. Psychol Med. 1998;28:551-8.

15. Gorenstein C, Andrade L. Inventário de Depressão de Beck: propriedades psicométricas da versão em português. Rev Psiquiatr Clín. 1998;25:245-50.

16. Beck AT, Ward CH, Mendelson M, Mock J \& Erbaugh J. An inventory for measuring depression. Arch Gen Psychiatry. 1961;4:561-71.

17. Guillamon N, Nieto R, Pousada M, Redolar D, Munoz E, Hernandez E, et al. Quality of life and mental health among parents of children with cerebral palsy: the influence of self-efficacy and coping strategies. J Clin Nurs. 2013;22:1579-90.
18. Mugno D, Ruta L, D’Arrigo VG, \& Mazzone L. Impairment of quality of life in parents of children and adolescents with pervasive developmental disorder. Health Qual Life Outcomes. 2007;5:22.

19. Tseng MH, Chen KL, Shieh JY, Lu L, Huang CY, Simeonsson RJ. Child characteristics, caregiver characteristics, and environmental factors affecting the quality of life of caregivers of children with cerebral palsy. Disabil Rehabil. 2016;38:2374-82.

20. Basaran A, Karadavut KI, Uneri SO, Balbaloglu O, Atasoy N. The effect of having a children with cerebral palsy on quality of life, burn-out, depression and anxiety scores: a comparative study. Eur J Phys Rehabil Med. 2013;49:815-22.

21. Okurowska-Zawada B, KuÅ,ak W, Wojtkowski J, Sienkiewicz D, Paszko-Patej G. Quality of life of parents of children with cerebral palsy. Prog Health Sci. 2011;1:116-23.

22. Eyigor S, Karapolat H, Yesil H, Kantar M. The quality of life and psychological status of mothers of hospitalized pediatric oncology patients. Pediatr Hematol Oncol. 2011;28:428-38.

23. Ferreira FS, Santos CBd. Qualidade de vida relacionada à saúde de pacientes diabéticos atendidos pela equipe saúde da família. Rev enferm UERJ. 2009;17:406-11.

24. Unalan H, Gencosmanoglu B, Akgun K, Karamehmetoglu S, Tuna H, Ones K, et al. Quality of life of primary caregivers of spinal cord injury survivors living in the community: controlled study with short form-36 questionnaire. Spinal Cord. 2001;39:318-22.

25. Zanon MA, Batista NA. Qualidade de vida e grau de ansiedade e depressão em cuidadores de crianças com paralisia cerebral. Rev. Paul. Pediatri. 2012.

26. Ahmadizadeh Z, Rassafiani M, Khalili MA, Mirmohammadkhani M. Factors associated with quality of life in mothers of children with cerebral palsy in Iran. Hong Kong J Occup Ther. 2015;25:15-22.

27. Yilmaz H, Erkin G, 凶zki AA. Quality of life in mothers of children with Cerebral Palsy. ISRN Rehabil. 2013; 2013.

28. Byrne MB, Hurley DA, Daly L, Cunningham CG. Health status of caregivers of children with cerebral palsy. Child Care Health Dev. 2010;36:696-702.

29. Ones K, Yilmaz E, Cetinkaya B, Caglar N. Assessment of the quality of life of mothers of children with cerebral palsy (primary caregivers). Neurorehabil Neural Repair. 2005;19:232-7.

30. Edwards L, Leafman JS. Perceptions of Gastrostomy Buttons Among Caregivers of Children With Special Health Care Needs- J Pediatr Health Care. 2019;33:270-9.

31. Kurien M, Andrews RE, Tattersall R, McAlindon ME, Wong EF, Johnston AJ, Hoeroldt B, Dear KL, Sanders DS. Gastrostomies preserve but do not increase quality of life for patients and caregivers. Clin Gastroenterol Hepatol. 2017; 15:1047-54.

32. Brehaut JC, Kohen DE, Raina P, Walter SD, Russell DJ, Swinton M, et al. The health of primary caregivers of children with cerebral palsy: how does it compare with that of other Canadian caregivers? Pediatrics. 2004;114:e182-91. 